\title{
ROLE OF LESHA KALPANA AS A TEXTUAL TOOL IN UNDERSTANDING VIMANASTHANA OF CHARAKASAMHITA
}

\author{
Dr. Teke Asmita Ravindra ${ }^{1 *}$, Dr. Chetan M. ${ }^{2}$, Dr. Samhita Ullod ${ }^{3}$ \\ ${ }^{1}$ Post Graduate Scholar, Department of Ayurveda Samhita and Siddhanta, SDM. College of \\ Ayurveda and Hospital, Hassan, Karnataka, India \\ 2Professor, Department of Ayurveda Samhita and Siddhanta, SDM. College of Ayurveda and \\ Hospital, Hassan, Karnataka, India \\ ${ }^{3}$ Assistant Professor, Department of Ayurveda Samhita and Siddhanta, SDM. College of Ayurveda \\ and Hospital, Hassan, Karnataka, India
}

*Corresponding Author : Dr. Teke Asmita Ravindra,

Article DOI: https://doi.org/10.36713/epra7090

DOI No: 10.36713/epra7090

\footnotetext{
ABSTRACT

Introduction

Lesha Kalpana is the textual tool one among the Saptavidha Kalpana used for better understanding and proper interpretation of Shastra. To put knowledge in a summarized and precise manner, Aacharya used peculiar methodologies while composing Shastra in the form of Sutras. By applying Lesha Kalpana to Ayurvedic Classics, guides the author and reader, brings the awareness of subject. Though Tantrayukti serves this purpose, Lesha Kalpana can be helpful to get Shastra's unambiguous meaning and interpretation.

Objectives

1. To study the concept of Lesha Kalpana.

2. To apply the Lesha Kalpana to Vimanasthana of Charakasamhita. Methodology

Literary sources of Lesha Kalpana collected and reviewed from the available sources. Lesha Kalpana employed in the verses of Vimanasthana was identified as per definition mentioned by Arunadatta and analyzed. Results tabulated and detailed interpretation of identified verse of Vimanasthana under the purview of Lesha Kalpana was carried out and conclusion drawn.

Result and Discussion

The Lesha Kalpana observed manifold applicability to enlighten the Vimanasthana in term of understanding the literary construction, Leshokta, Anuktartha and Sandigdhartha of sutras and to interpret the concepts for its practical utility. Vimanasthana is a very unique section which plays the role mainly for diagnosis of disease and treatment purpose. Application of Lesha Kalpana to this Sthana aid comprehension of subject specified understanding.

Conclusion

Present study effectively emphasizes the very need of the compositional tool Lesha Kalpana to systematically study a Shastra, to understand literary construction, analysis and interpretation and also serves its utility for practical application of analyzed concepts.
}

KEY WORDS: Tantraguna; Lesha Kalpana; Vimanasthana. 


\section{INTRODUCTION}

Ayurveda science, the knowledge of longevity is the traditional healing modality of the Vedic culture in India. In ancient time this science was in the form of Shruti (what is heard) and Smruti (memorization) heritage; as there were not availabilities of technologies. This Vangamaya tradition of learning science ${ }^{1}$, in course of time created to literary tradition known as Samhita. That time period verses were abided by the rules of Sanskrit language as the knowledge of Sanskrit language was the prime education. This leads to formation of leshokta (partly explained), Anukta (not mentioned) verses; so meaning of some verses remained hidden. Hence for the better understanding, Aacharya has used various methodologies to make Samhita study easier ${ }^{2}$. The textual tool Lesha Kalpana aids to fulfil above.

The Vimanasthana of Charaka Samhita is the conglomeration of basic principles of Ayurveda deals with specific knowledge of dosha, bheshaja etc. and many concepts which play role in diagnosis of disease and treatment ${ }^{3}$ and hence it can be considered as the most important Section. By knowing it knowledge of them needed for physician can be met with. So for that Vimanasthana is considered for present study.

\section{REVIEW OF LITERATURE}

Aacharya Arunadatta in the 'Sarvangasundara' commentary of Ashtanga Hrydaya has mentioned various methodologies under Tantraguna like Tantrayukti, Tatchhilya, Arthashraya and Kalpana4. Kalpana is a device which helps to understand the structural construction and specific style of writing adopted by author. These are Pradhanasya, Pradhanena, Guna, Lesha, Vidya, Ajna and Bhakshya Kalpana known as Saptavidha Kalpana ${ }^{5}$. The Lesha Kalpana is a methodology one among Saptavidha Kalpana adopted by the author for the better understanding of the Science.

By the application of this Kalpana to verse hidden, unexplained matter can be identified and interpretation will help for the conceptual and clinical applications.

\section{Lesha Kalpana -}

The word meaning of Lesha is a small part, bit or portion, a particle, an atom, a very small quantity ${ }^{6}$. Aacharya Arunadatta has mentioned it as, when the Sutra is described partially or not described in detail; some topics are not elaborated due to their vastness or any other reasons, such topics can be understood based on described fact which is depending on aphorism. If brief note is given but have to think elaborately by references and experience is the Lesha Kalpanas.

\section{Need of Lesha concept in Tantra:}

Ayurveda texts are composed in a typical Samhita form where Samhita refers to rule based combination of verse and prose $^{7}$, targeted for the recitation and memorization of verse easily. The composition of verse has some guidelines.

Aacharya in Mugdhabodha commentary of Vayupurana has defined the verse as, verse form follows some obvious reservations of expression i.e. elaboration. Thus in Samhita didn't find discussion of each and every detail of subject. The text discusses about some representative samples and expects the reader to derive more on the basis of explained8. Aacharya Vagbhata has also mentioned that, wise Physician should use his own intellect to understand the remaining things based on the explained one 9 .

In Charakasamhita it is quoted that, It is the Tantrashailli (style of writing) adopted by author where the thing mentioned in sankshepa (brief) is the Leshokta are elaborated and those which are in vistara (elaborated) are made in brief in the text everywhere according to the need of Samhita ${ }^{10}$.

Reasons for the Lesha sutra in Tantra:

The reasons can be categorized under Personal reasons and Technical reasons ${ }^{11}$.

a) Personal reasons :

Sometimes author may not feel the need of elaboration of some specific topic as then the disciple can easily pick up the unsaid because of the proximity with teacher and other context.

b) Technical reasons :

Writing style of texts-

All ancient texts are composed in the Samhita form. As the definition of Samhita is 'parah sannikarshah samhita'. This Samhita form expects and enjoys being 'in brief' and this comes with its style of representation.

Aacharya Charaka has mentioned that, there is no limit for vistara (elaboration) hence wise Physician can elaborate the topic where it is leshokta or anukta and it is sufficient for less intellectual person to practice. Aacharya Vagbhata has also accepted this form for 'geyata' (easy to recite). Thus, it has also brought about the Lesha form.

\section{Limits of Tantra-}

The ancient text discusses Ayurveda in general, but they have focused perspective of domain.

E.g. Charaka Samhita is explained with consideration of Adhikarana (main heading) as Kayachikitsa. Sushruta Samhita is explained with consideration of Adhikarana (main heading) as Shalya tantra. Hence they have limited themselves to their Adhikarana only and have left apart the things which are out of main heading. Such left out topic become 'Leshokta' for that particular text. Here, the verse 'paradhikareshu na vistarokti'12 where Aacharya 
mentioned that it is not my adhikarana so it is not elaborated.

Identification of Leshokta:

Very general guidelines to identify the Leshokta sutras are 'aadi, aadayah, sankshepatah, iti, evam, aadibhihi, lakshanaodaharanartham, yathoktam, uktani bhagashah, purvavat, vividhaihi, idrusham, '13. These words which come in sutras specifically suggest 'Leshokta'.

General methods of decoding ${ }^{14}$ :

The general methods which can be considered as methods of elaboration of any Sutras are mentioned by Aacharya Charaka are, Vakyashah, Vakyavayavashaha and Arthavayavashah understanding of sutras. This guideline is not exactly refers the elaboration of Lesha sutra but can be considered as how to elaborates it.

General Steps of elaboration of Lesha Sutra ${ }^{15}$ :

By applying these methods Lesha sutras can be elaborated.

1. Literary meaning

2. Discussion

3. Leshokta Sutra

4. Elaboration

a) To fix the position of sutras as a base for further elaboration

b) Swa-Tantravalokana- compilation of references from leshokta sutra Grantha

c) Para-Tantravalokana- compilation of references from other Grantha

d) Elaboration based on the above.

Similarity of Lesha Kalpana with other Tantraguna By the overlook, this Kalpana is having similarity with the other Tantragunas like Vakyashesha, Uddesha and Pradesha Tantrayuktis. Here, Lesha Kalpana differs from Vakyashesha Tantrayukti; where few words are omitted in a sutra and supply of missing words gives complete and clear knowledge of that sutra. In the Lesha Kalpana partial information is given, meaning of entire sutra has to be inferred from partial explanation. The Uddesha Tantrayukti is a concise statement which is elaborated in the form of Nirdesha Tantrayukti at some other place. In the Pradesha Tantrayukti only a part of topic is explained due to the vastness of it in the Samhita ${ }^{16}$. Hence description of Lesha Kalpana is overlapping with the Pradesha Tantrayukti in some way.

Aims and objectives:

1. To study the concept of Lesha Kalpana.

2. To apply the Lesha Kalpana to Vimanasthana of Charakasamhita.

\section{METHODOLOGY}

Literary sources of Lesha Kalpana collected and reviewed from the available sources. Lesha Kalpana employed in the Sutras of Vimanasthana was identified as per definition mentioned by Arunadatta and analyzed. Results tabulated and detailed interpretation of identified sutras of Vimanasthana under the purview of Lesha Kalpana was carried out.

\section{RESULT}

Total thirteen Lesha Kalpana identified based on definition mentioned by Arunadatta. The result has been tabulated in terms of context, reference and the words by which it has been considered under Lesha Kalpana. The use of words like 'anyat, anyebhyo, aadibhihi, anyashcha, anyaani uktaani, katichit prakara, aadi etc. are observed in Vimanasthana mainly suggested that, sutra contain Leshokta matter.

A list of various Lesha Kalpana found throughout the Vimanasthana is mentioned in Table No.1

\section{DISCUSSION}

The Samhita type composition form of Ayurveda texts led down to form Leshokta or Anukta Sutra. Lesha Kalpana shows the avoidance of Tantradosha (faults) in the texts like Atigrantha Vistara, Punarukta Dosha. Explained matter is sufficient to practice for less intellectual person, Anukta or Leshokta can be understood by high intellectual persons ${ }^{17}$ hence Lesha Kalpana is useful for all types of intellectual persons. As the Lesha Kalpana is the method adopted by author, shows its utility mainly for gaining the Vakyartha (to understand the entire sentence or Verse).

The literary study revealed that manifold applications of Lesha Kalpana are useful to enlighten the Vimanasthana while reading. It provides both conceptual understanding as well as practical applications. By understanding of this Physician can use these applications in Vyadhi nidana and Chikitsa.

E.g.1. In the 'Rasavimanam Adhyaya', in the context of Ashtavidha Aahara Vidhivishesha Aayatana (directions for ingestion of food), Aacharya has explained about the Karana aayatana. Here, the Samskara (alteration in original quality) which will be done to change the qualities of natural drug is known as Karana and mentioned many procedures by which the alteration of qualities in a drug can be achieved ${ }^{18}$. Like - 'Jalasamyoga, Agnisannikarsha, Shoucha, Manthana, Desha, Kala, Vasana, and Bhavana'. In the verse the word 'aadibhihi'suggests that, there is other many other procedures for the alteration of qualities in drugs. Due to fear of vastness these are not mentioned but wise Physician should understand these by the explained part. This is the Leshokta sutra where most commonly practiced procedures are mentioned and uncommon procedures have to be understood by the explained one.

These procedures can be included as 'Peshana, Abhimantrana's, samana guna prayoga, viparita guna prayoga, samana guna samyoga of 
dravya, viparita guna samyoga of dravya’. Aacharya Hemadri mentioned the procedures like Vidalikarana, Nistushikarana for the alteration of qualities in a drug ${ }^{19}$. Here Physician can use these procedures as per suitability, disease, constitution, place etc. and plan the food and medicine as a diet and treatment respectively.

E.g.2. In the 'Trividhakuksheeyam Vimanam Adhyaya', Aacharya explained the aamapradoshaja vikara (diseases due to undigested food) and their treatment. Here, after explaining the treatment, Aacharya advised that, the person should always think about what is beneficial and harmful food to body. This is based on the ashtavidha aaharavidhi vishesha aayatana. These are causes for the benefits of Aaharavidhi like intake of warm, fresh food etc. Aacharya advised that, if the person takes the food by the proper examination of these aayatana, aama (undigested food) will not be formed and thereby the diseases due to undigested food can be avoided.

In this verse 'anyashcha iha kashchit' word refers to other beneficial methods which do the aamakshaya (digests the undigested food). This is the Leshokta sutra where the common beneficial factors are mentioned and specific have to be understood by explained one. These can be understood as a various diseases which are aamashaya samuttha (originated from aamashaya) like Arsha, Grahani, Atisara, jwara, chhardi etc ${ }^{20}$. These diseases are mainly caused by Agni dushti (deranged digestion power) and aama dosha and their treatment mainly concentrates to do the Agni dipana (increase the digestion power) and digests the undigested food. Hence aamakshayakar chikitsa can be adopted to get the benefits of food ${ }^{20}$.

Aacharya Vagbhata also mentioned that, the person should take the light, food containing all six Rasas without disrespect of food. The causes which increase the aama like Samashana, Adhyashana and Vishamashana should be avoided ${ }^{21}$.

Other partially explained verses observed in Vimanasthana also revealed its utility in conceptual understanding and the practical applications. As Vimanasthana is a very unique section, Physician can apply these applications in the diagnosis of disease and plan the treatment accordingly which will definitely aids comprehension of subject specified understanding.

\section{CONCLUSION}

Conceptual review on Lesha Kalpana revealed avoidance of the Tantradoshas like Grantha vistara and Punarukti dosha by the form of Lesha Sutras. This Kalpana serves the prayojana of compositional tools like to gain the Vakyartha. Many concepts in Vimanasthana which are partially explained or not explained can be better understood by the application of this Kalpana and thereby are helpful in the clinical practice. Applications of Lesha Kalpana observed in Vimanasthana effectively emphasizes the very need of the this tool to systematically study a Shastra, to understand literary construction, analysis and interpretation and also serves its utility for practical application of analyzed concepts.

Table No.1 Lesha Kalpana observed in Vimanasthana of Charaka Samhita.

\begin{tabular}{|c|l|l|l|}
\hline $\begin{array}{c}\text { Sl } \\
\text { No. }\end{array}$ & Reference & Context & Observed by words \\
\hline 1 & Cha. Vi.1/14 & Dravya prabhava & Anyat api dravyam \\
\hline 2 & Cha. Vi.1/15 & Dravya prayoga nishedha & Anyebhyo dravyebhyah \\
\hline 3 & Cha. Vi.1/21(2) & Karana & Aadibhihi \\
\hline 4 & Cha.Vi 2/14 & Aama pradoshaja chikitsa & Anyashcha iha kashchit \\
\hline 5 & Cha.Vi.3/22 & $\begin{array}{l}\text { Janapadodhwamsa hetu by } \\
\text { Rakshasa }\end{array}$ & Anyat apachara \\
\hline 6 & Cha. Vi. 4/7 & Pratyakshya gamya bhava & Anye api, anyaani uktaani \\
\hline 7 & Cha.Vi.5/7 & Stroto vijnana & Katichit prakara \\
\hline 8 & Cha. Vi. 5/10 & $\begin{array}{l}\text { Pranavah strotas dushti } \\
\text { hetu }\end{array}$ & $\begin{array}{l}\text { Strotamsi anyaishch } \\
\text { darunaihi }\end{array}$ \\
\hline 9 & Cha. Vi. 6/3 & Vyadhi asankhyeyata & $\begin{array}{l}\text { Bahutwam api sankhyeyam } \\
\text { syat asankhyeyam va }\end{array}$ \\
\hline 10 & Cha. Vi. 7/20 & $\begin{array}{l}\text { Shirogata krimihara } \\
\text { dravya }\end{array}$ & $\begin{array}{l}\text { Upapaadya } \\
\text { apamargatandulina }\end{array}$ \\
\hline 11 & Cha. Vi. 8/40 & Anumana vadamarga & Ishtam cha kevala jnana \\
\hline 12 & Cha. Vi. 8/137 & Aasthapana basti dravya & Aadi \\
\hline 13 & Cha. Vi. 8/150 & Anuvasana upayogi dravya & Sarvatah tailam pradhanyat \\
\hline
\end{tabular}

\section{REFERENCES}

1. Sharma S. (2008), "Ashtanga Sangraha of Vagbhata," Chaukhmbha Sanskrit Series, Varanasi, P:958.
2. Aacharya JT, (2015), "Charaka Samhita of Agnivesha" Chaukhambha Orientalia, Varanasi P:737

3. Aacharya JT, (2015), "Charaka Samhita of Agnivesha" Chaukhambha Orientalia, Varanasi 


\section{$P: 231$}

4. Paradakar BH, (2017), "Ashtanga Hrydaya of Vagbhata” Chaukhamba Orientalia, Varanasi, P:946

5. Paradakar BH, (2017), "Ashtanga Hrydaya of Vagbhata" Chaukhamba Orientalia, Varanasi, P:950

6. Apte VS, (1970), "The Student's SamskritEnglish Dictionary”, Motilala Banarasidas Publishers Private Limited, Delhi,P:188.

7. Radhakanthadeva (1987), "Shabdakalpadruma", Naga Publishers, Delhi, P: 208.

8. Radhakanthadeva, (1987), "Shabdakalpadruma", Chaukhamba Sanskrit Series Office, Varanasi, P:394.

9. Sharma S. (2008), "Ashtanga Sangraha of Vagbhata," Chaukhmbha Sanskrit Series, Varanasi, P:71.

10. Aacharya JT, (2015), "Charaka Samhita of Agnivesha" Chaukhambha Orientalia, Varanasi P:735

11. Bavadekar LS, (2018), "Decoding Leshokta", Swasthya Niketana Pune,P:18-19.

12. Aacharya JT, (2015), "Charaka Samhita of Agnivesha" Chaukhambha Orientalia, Varanasi $P: 34$

13. Bavadekar LS, (2018), "Decoding Leshokta", Swasthya Niketana Pune, P:20.

14. Aacharya JT, (2015), "Charaka Samhita of Agnivesha" Chaukhambha Orientalia, Varanasi P:186

15. Bavadekar LS, (2018), "Decoding Leshokta", Swasthya Niketana Pune,P:23.

16. Aacharya JT, (2015), "Charaka Samhita of Agnivesha" Chaukhambha Orientalia, Varanasi P:736.

17. Aacharya JT, (2015), "Charaka Samhita of Agnivesha" Chaukhambha Orientalia, Varanasi $P: 250$.

18. Aacharya JT, (2015), "Charaka Samhita of Agnivesha" Chaukhambha Orientalia, Varanasi $P: 235$.

19. Paradakar BH, (2017), "Ashtanga Hrydaya of Vagbhata" Chaukhamba Orientalia, Varanasi, P:90

20. Aacharya JT, (2015), "Charaka Samhita of Agnivesha" Chaukhambha Orientalia, Varanasi $P: 240$

21. Paradakar BH, (2017), "Ashtanga Hrydaya of Vagbhata" Chaukhamba Orientalia, Varanasi, P:155 